Supporting information for

\title{
Self-Immolative Dye-Doped Polymeric Probe for Precisely Imaging Hydroxyl Radicals by Avoiding Leakage
}

Yibo Zhou, ${ }^{*, a}$ Hao Dong, ${ }^{a}$ Zhengxuan Gu, ${ }^{\text {a }}$ Sheng Yang, ${ }^{\text {a,b }}$ Minzhi Ouyang, ${ }^{\mathrm{c}}$ Zhihe Qing, ${ }^{a}$ Xiaofei Ma, ${ }^{a}$ Shan $\mathrm{Hu},{ }^{a}$ JunBin $\mathrm{Li},{ }^{a}$ and Ronghua Yang*,a,b

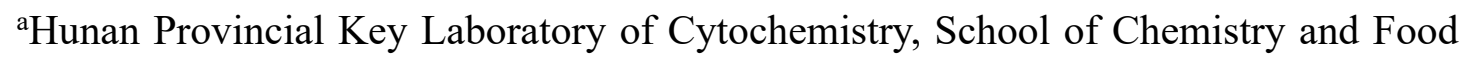
Engineering, Changsha University of Science and Technology, Changsha, 410114, P. R. China.

${ }^{\mathrm{b}}$ Key Laboratory of Chemical Biology \& Traditional Chinese Medicine Research, Ministry of Education, College of Chemistry and Chemical Engineering, Hunan Normal University, Changsha, 410081, P. R. China.

'Department of Ultrasound Diagnosis, Second Xiangya Hospital, Central South University, Changsha, 410011, P. R. China.

*To whom correspondence should be addressed:

E-mail: yibozhou@163.com

E-mail: yangrh@pku.edu.cn

Fax: $+86-731-88822523$ 


\section{Table of Contents}

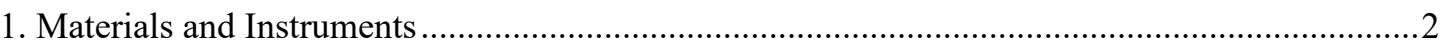

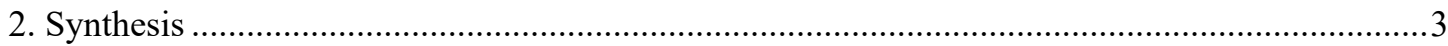

3. Critical Micellar Concentration (CMC) of the Polymer ....................................................5

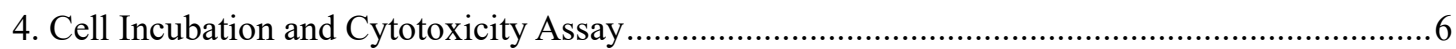

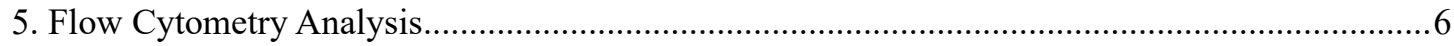

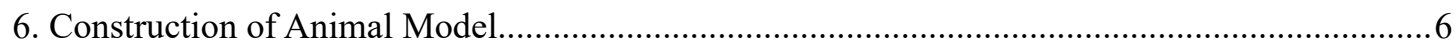

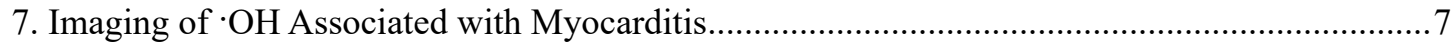

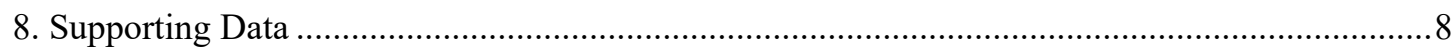

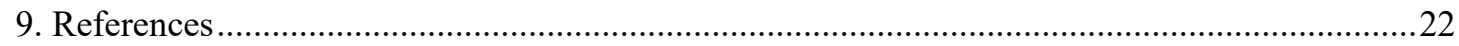

\section{Materials and Instruments}

All the chemicals used for synthesis were analytical grade and purchased from commercial suppliers. The hydroxyl radical $(\cdot \mathrm{OH})$ was produced by Fenton reagent $\left(\mathrm{FeSO}_{4}: \mathrm{H}_{2} \mathrm{O}_{2}=1: 6\right)$. The water used in this work was purified with Milli-Q water system (Millipore, USA), and the dried tetrahydrofuran (THF), dichloromethane (DCM) and dimethylformamide (DMF) were obtained by refluxing over 24 hours in flask contained calcium hydride. The H9C2 cells were obtained from analysis and test center of Central South University, and the BALB/c mice were obtained from Hunan Slaccas Jingda Laboratory Animal Co., Ltd.

${ }^{1} \mathrm{H}$ spectra were recorded by Invoa-400 spectrometer and mass spectra were recorded on LCQ/Advantage HPLC-Mass spectrotometer. GPC was performed on a Waters 1515. The fluorescence spectra were recorded by Photon Technology Intl. Transmission electron microscope (TEM, JEOL 1200 EXII) and dynamic light scattering (DLS, Malvern Zetasizer 3000 HS) were used to characterize the nanoprobes. FACScan cytometer (Accuri C6 plus) was used to accurately assess the fluorescence intensity of living cells incubated with SDPP. MTT assay was measured with Benchmark Plus (Bio-Rad Instruments Inc., Japan). Fluorescence images of cells were 
obtained by FV3000 laser scanning confocal microscope (Olympus, Japan). The fluorescence images of nude mice and organs were obtained via an IVIS Lumina III Imaging System (Caliper, U.S.A.).

\section{Synthesis}

\section{Synthesis of Compounds 1-5.}

2-hydroxy-5-methyl-1,3-benzenedimethanol (1000 mg, $5.95 \mathrm{mmol})$ and imidazole (890 mg, $13.08 \mathrm{mmol})$ were mixed in round-bottomed flask $(25 \mathrm{~mL})$ contained with dry DMF $(5 \mathrm{~mL})$, then the mixture was cooled to $0{ }^{\circ} \mathrm{C}$ in the ice-water bath. TertButyldimethylsilyl chloride (1970 mg, $12.69 \mathrm{mmol}$ ) was dissolved in dry DMF (3 mL) and added dropwise to the reaction flask, and then the mixture was stirred for $2 \mathrm{~h}$ at room temperature. Then, the reaction mixture was diluted with ether and washed with water, and the organic layer was condensed under reduced pressure. At last, the concentrated crude product was purified by flash-chromatography on silica gel $(\mathrm{Hex} / \mathrm{EtOAc}=95: 5)$ to give compound 1 as colorless oil $(2170 \mathrm{mg}, 95 \%) .{ }^{1}{ }^{1} \mathrm{H}$ NMR (400 MHz, $\left.\mathrm{CDCl}_{3}\right): \delta=7.89(\mathrm{~s}, 1 \mathrm{H}), 6.78(\mathrm{~s}, 2 \mathrm{H}), 4.70(\mathrm{~s}, 4 \mathrm{H}), 2.13(\mathrm{~s}, 3 \mathrm{H}), 0.82(\mathrm{~s}$, 18H), 0.02 (s, 12H). ESI-MS (+): for $\mathrm{C}_{21} \mathrm{H}_{40} \mathrm{O}_{3} \mathrm{Si}_{2}$ : 397.49; found: 396.7 .

Compound 1 (940 mg, $2.36 \mathrm{mmol}$ ), 4-bromoanisole (662 mg, $3.54 \mathrm{mmol}$ ) and $\mathrm{K}_{2} \mathrm{CO}_{3}(490 \mathrm{mg}, 3.54 \mathrm{mmol})$ were dissolved in flask with acetone $(5 \mathrm{~mL})$. The mixture was stirred for $12 \mathrm{~h}$ at $50{ }^{\circ} \mathrm{C}$, then the solution was cooled to room temperature and the solvent was removed under reduced pressure. After that, the reaction mixture was washed with saturated $\mathrm{NH}_{4} \mathrm{Cl}$ solution and brine. The obtained organic layer was dried with $\mathrm{MgSO}_{4}$ and further evaporated under reduced pressure. The crude product was purified by silica gel flash chromatography $(\mathrm{Hex} / \mathrm{EtOAc}=95: 5)$ to give compound 2 as opalescent solid (770 mg, $65 \%$ ). ${ }^{1} \mathrm{H}$ NMR (400 MHz, DMSO-d $)$ : $\delta=7.30$ (d, 2H), 7.21 (d, 2H), $7.12(\mathrm{~s}, 2 \mathrm{H}), 4.78(\mathrm{~s}, 4 \mathrm{H}), 3.81(\mathrm{t}, 3 \mathrm{H}), 2.37$ (s, 3H), 0.97 (s, 18H), 0.03 (s, 12H). ESI-MS (+): for $\mathrm{C}_{28} \mathrm{H}_{46} \mathrm{O}_{4} \mathrm{Si}_{2}$ : 502.85; found: 501.9.

Compound 2 (160 mg, $0.32 \mathrm{mmol})$ and p-toluenesulfonic acid (10 mg, $0.06 \mathrm{mmol})$ were dissolved by methanol $(1 \mathrm{~mL})$ in flask $(5 \mathrm{~mL})$, the mixture was stirred for $2 \mathrm{~h}$ at room temperature. Then the solvent was removed under reduced pressure and the crude 
product was purified by silica gel flash chromatography $(\mathrm{Hex} / \mathrm{EtOAc}=1: 1)$ to give

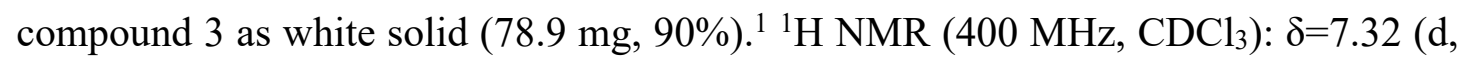
2H), $7.18(\mathrm{~d}, 2 \mathrm{H}), 7.09$ (d, 2H), $4.72(\mathrm{~s}, 4 \mathrm{H}), 3.91(\mathrm{t}, 3 \mathrm{H}), 2.21$ (s, 3H). ESI-MS (+): for $\mathrm{C}_{16} \mathrm{H}_{18} \mathrm{O}_{4}$ : 274.32; found: 274.1 .

2,6-dimethylbenzyl alcohol (500 mg, $3.67 \mathrm{mmol}$ ), 4-bromoanisole (1030 mg, 5.51 $\mathrm{mmol})$ and $\mathrm{K}_{2} \mathrm{CO}_{3}(760 \mathrm{mg}, 5.51 \mathrm{mmol})$ were dissolved in acetone $(5 \mathrm{~mL})$. The mixture was stirred for $12 \mathrm{~h}$ at $50{ }^{\circ} \mathrm{C}$, then the solution was cooled to room temperature and the solvent was removed under reduced pressure. The residue is separated and purified by column chromatography $(\mathrm{Hex} / \mathrm{EtOAc}=80: 20)$ to obtain the compound $4(700 \mathrm{mg}$, 79.3\%). ${ }^{1}{ }^{1} \mathrm{H}$ NMR (400 mHz, DMSO- $\left.d_{6}\right): \delta=7.4(\mathrm{t}, 1 \mathrm{H}), 7.21(\mathrm{~d}, 2 \mathrm{H}), 7.08(\mathrm{q}, 2 \mathrm{H}), 6.99$ (d, 2H), 4.74 (s, 2H), $3.70(\mathrm{~s}, 3 \mathrm{H}), 2.42$ (s, 6H).

Compound 4 (55.7 mg, $0.23 \mathrm{mmol})$, AIBN (114.9 mg, $0.7 \mathrm{mmol}$ ) and NBS (86.6 $\mathrm{mg}, 0.48 \mathrm{mmol})$ were added to the flask contained with carbon tetrachloride $(5 \mathrm{~mL})$. The mixture was stirred overnight at $90^{\circ} \mathrm{C}$, then the residue was filtered and concentrated under reduced pressure. At last, the solid was purified on silica gel with EtOAc/Hexanes to obtain compound 5 (50.6 mg, 55\%). ${ }^{1}{ }^{1} \mathrm{H} \mathrm{NMR}\left(400 \mathrm{mHz}, \mathrm{CDCl}_{3}\right)$ : $\delta=7.44(\mathrm{t}, 1 \mathrm{H}), 7.24(\mathrm{~d}, 2 \mathrm{H}), 7.01(\mathrm{q}, 2 \mathrm{H}), 6.84(\mathrm{~d}, 2 \mathrm{H}), 5.21(\mathrm{~s}, 2 \mathrm{H}), 4.68(\mathrm{~s}, 4 \mathrm{H}), 3.81$ $(\mathrm{s}, 3 \mathrm{H})$.

\section{Synthesis of Polymer 1-3.}

The synthesis routes of polymers were described in Scheme 2 and Scheme S1. Firstly, compound 3 (274.1 mg, $1.0 \mathrm{mmol})$ was dissolved in DCM (25 mL) containing SQ (542 mg, $1.0 \mathrm{mmol})$, then the mixture of DCC (122 mg, $0.6 \mathrm{mmol})$ and DMAP (73 $\mathrm{mg}, 0.6 \mathrm{mmol}$ ) was added and stirred overnight at room temperature under argon atmosphere. Then the crude product was cooled to $0{ }^{\circ} \mathrm{C}$ and added with $\mathrm{BBr}_{3}$ dropwise, and the solution was warmed up to room temperature and stir for another $3 \mathrm{~h}$. Next, water was added carefully to stop the reaction, the solution was still stirred until all precipitates were dissolved. The residue was further purified by repeated reprecipitations in cold ethanol $(4 \times 10 \mathrm{~mL})$ to give polymer 1 as green solid $(617.5 \mathrm{mg}$, 77.3\%). ${ }^{1,2}{ }^{1} \mathrm{H}$ NMR (400 mHz, DMSO- $\left.d_{6}\right): \delta=7.71(\mathrm{t}, 2 \mathrm{H}), 7.47(\mathrm{~s}, 2 \mathrm{H}), 7.26(\mathrm{~s}, 2 \mathrm{H})$, 
$7.23(\mathrm{~s}, 4 \mathrm{H}), 7.17(\mathrm{~s}, 2 \mathrm{H}), 7.06(\mathrm{~s}, 2 \mathrm{H}), 5.44(\mathrm{~s}, 2 \mathrm{H}), 4.61(\mathrm{~s}, 4 \mathrm{H}), 4.19(\mathrm{t}, 4 \mathrm{H}), 2.23(\mathrm{~s}$, 4H), 2.14 (s, 3H), 1.35 (m, 12H). GPC (THF, RT): $M_{\mathrm{n}}=1308 \mathrm{~g} / \mathrm{moL}, \mathrm{PDI}=1.15$.

Secondly, the compound $3(383.7 \mathrm{mg}, 1.41 \mathrm{mmol})$ and adipoyl chloride $(0.6 \mathrm{~mL}$, $1.38 \mathrm{mmol})$ were diluted with dry DCM $(4 \mathrm{~mL})$ in round-bottomed flask $(25 \mathrm{~mL})$. Then, triethylamine (600 $\mu \mathrm{L}, 4.2 \mathrm{mmol})$ was added dropwise to the reaction flask, and the reaction mixture was stirred for $1 \mathrm{~h}$ at room temperature. After that, the crude mixture was cooled to $0{ }^{\circ} \mathrm{C}$ and react with $\mathrm{BBr}_{3}$ as the synthesis of polymer 1 . At last, the residue was further purified by repeated reprecipitations in cold ethanol $(4 \times 10 \mathrm{~mL})$ to give polymer 2 as white solid (336.3 mg, 60\%). ${ }^{1,2} \mathrm{H}$ NMR (400 MHz, DMSO- $d_{6}$ ): $\delta=7.25$ (d, 2H), $7.13(\mathrm{~d}, 2 \mathrm{H}), 6.92(\mathrm{t}, 2 \mathrm{H}), 5.0(\mathrm{~s}, 4 \mathrm{H}), 2.3(\mathrm{~s}, 3 \mathrm{H}), 2.21(\mathrm{~s}, 4 \mathrm{H}), 1.59(\mathrm{t}, 4 \mathrm{H})$. GPC (THF, RT): $M_{\mathrm{n}}=2311.3 \mathrm{~g} / \mathrm{moL}, \mathrm{PDI}=1.18$.

At last, tetrabutylammonium hydroxide $\left(2.9 \mathrm{~mL}, 40 \% \mathrm{H}_{2} \mathrm{O}\right)$ was added to the flask contained with SQ $(864.2 \mathrm{mg}, 1.6 \mathrm{mmol})$, then the compound $5(640 \mathrm{mg}, 1.6 \mathrm{mmol})$ was dissolved with chloroform $(6.2 \mathrm{~mL})$ and added. The mixture was stirred overnight at $62{ }^{\circ} \mathrm{C}$ to complete the polyreaction, then the crude mixture was cooled to $0{ }^{\circ} \mathrm{C}$ and react with $\mathrm{BBr}_{3}$ as the synthesis of polymer 1 . After that, the residual was partitioned by DCM and buffer solution. The obtained organic layer was further washed with brine and the filtrate was concentrated. Finally, the crude solid was further purified by gel

fitration to remove the smaller oligomers $(1198.1 \mathrm{mg}, 95 \%) .{ }^{1,2}{ }^{1} \mathrm{H}$ NMR (400 MHz, DMSO- $\left.d_{6}\right): \delta=7.56(\mathrm{t}, 2 \mathrm{H}), 7.38(\mathrm{t}, 2 \mathrm{H}), 7.18(\mathrm{t}, 2 \mathrm{H}), 7.06(\mathrm{~s}, 4 \mathrm{H}), 6.95(\mathrm{~s}, 2 \mathrm{H}), 6.88(\mathrm{~s}$, 2H), $5.51(\mathrm{~d}, 2 \mathrm{H}), 4.83(\mathrm{~m}, 4 \mathrm{H}), 4.7(\mathrm{t}, 2 \mathrm{H}), 4.31(\mathrm{~d}, 4 \mathrm{H}), 2.29(\mathrm{q}, 4 \mathrm{H}), 1.2(\mathrm{~m}, 12 \mathrm{H})$. GPC (THF, RT): $M_{\mathrm{n}}=1636 \mathrm{~g} / \mathrm{moL}, \mathrm{PDI}=1.06$.

\section{Critical Micellar Concentration (CMC) of the Polymer}

We use a fluorescent probe method to test the critical micellar concentration (CMC) of polymers. ${ }^{3}$ The Nile Red solution $(0.1 \mathrm{mg} / \mathrm{mL}, 30 \mu \mathrm{L})$ was mixed with different concentration of polymers $(0.00001,0.000025,0.00005,0.0001,0.00025$, $0.0005,0.001,0.005,0.01,0.05,0.1$ and $0.2 \mathrm{mg} / \mathrm{mL}$ ) in centrifuge tube, and the mixture was stirred for $12 \mathrm{~h}$ at room temperature, then the fluorescence spectra was recorded from 570 to $750 \mathrm{~nm}$ with the excitation wavelength of $550 \mathrm{~nm}$. 


\section{Cell Incubation and Cytotoxicity Assay}

The rat cardiomyocytes (H9C2) cells were chosen to investigate the performance of SDPPs. All the cells were cultured in Dulbecco's modified Eagle's medium (DMEM, GIBCO) supplemented with fetal bovine serum (FBS, $10 \%$, GIBCO) at $37{ }^{\circ} \mathrm{C}$ under $5 \%$ $\mathrm{CO}_{2}$.

The biocompatibility of nanoprobes was evaluated by standard cell viability assaythe MTT assay. H9C2 cells $\left(1 \times 10^{4}\right)$ were cultured in 96-well microplates at $37^{\circ} \mathrm{C}$, then the culture medium was removed and the cells were incubated with different concentration of nanoprobes for another $24 \mathrm{~h}$. After that, the culture medium was removed and MTT solution ( $100 \mu \mathrm{L}, 0.5 \mathrm{mg} / \mathrm{mL})$ was added for incubation for another $4 \mathrm{~h}$. Then, DMSO $(150 \mu \mathrm{L})$ was added to each well and the plate was shaken for $10 \mathrm{~min}$ at room temperature. At last, absorbance of the samples was recorded with Tecan microplate (ELISA) reader. The cell viability was calculated with the following equation. $^{4}$

$$
\text { Cell viability }=\left[\mathrm{OD}_{570(\text { (sample })}-\mathrm{OD}_{570(\text { blank })}\right] /\left[\mathrm{OD}_{570(\text { control })}-\mathrm{OD}_{570(\text { blank })}\right]
$$

\section{Flow Cytometry Analysis}

Flow cytometry analysis was used to assess the fluorescence intensity of cells incubated with SDPP $(120 \mu \mathrm{g} / \mathrm{mL})$. The different group of cells were pre-treated with stimulants and then incubated with SDPP $(120 \mu \mathrm{g} / \mathrm{mL})$, then the cells was removed from culture dish with trypsin $(0.5 \mathrm{~mL})$. The obtained cells were centrifuged with speed of $1000 \mathrm{rpm}$ for $4 \mathrm{~min}$ and washed with PBS, then the fluorescence intensity was examined with flow cytometry by counting 10000 events.

\section{Construction of Animal Model}

Adult BALA/C-NU nude mice (8-weeks old, 17 20 g) were purchased from Hunan SJA Laboratory Animal Co., Ltd and raised in pathogen-free conditions. After being allowed to adapt to environmental conditions for 5 days, the mice were divided into three groups randomly ( $\mathrm{n}=3$ for each group). During the next two weeks, the 
experimental group was intraperitoneal injected with doxorubicin hydrochloride (4.4 $\mathrm{mg} / \mathrm{mL}, 38 \mu \mathrm{L}$ for each mouse) for three times to construct the cardiopathic mice model (the cumulative dose is $30 \mathrm{mg} / \mathrm{kg}$ ). As a comparison, the control group was feed with irradiated feed and sterile water freely. After that, two of the cardiopathic mice were intraperitoneal injected with MCI-186 (10 mg/mL, $18 \mu \mathrm{L}$ for each mouse) for one week uninterruptedly (the cumulative dose is $70 \mathrm{mg} / \mathrm{kg}$ ) to build the convalescent model.

\section{Imaging of $\cdot \mathrm{OH}$ Associated with Myocarditis}

Various mice were intraperitoneally injected with SDPP $(120 \mu \mathrm{g} / \mathrm{mL})$ and then imaged with small animal imaging system (MIDMARK Matrx VMR) after $4 \mathrm{~h}$. Before that, the mice were anesthetized with isoflurane gas $(2.0 \mathrm{~mL} / \mathrm{min}$, mixed with oxygen $(1.0 \mathrm{~mL} / \mathrm{min}))$, then the anesthetized mice were placed in the anaesthetic mask of camera obscura for imaging. In this section, the default settings of imaging software were used (exposure time was $1 \mathrm{~s}$, binning was 8 , f/stop was 1 ), the excitation wavelength was $600 \mathrm{~nm}$ and emission range was 670-740 nm. Also, the organs separated from control group and experimental group were imaged under the same conditions. After that, the inflamed and normal hearts were handed over to Testing Organization for immunohistochemical analysis. 


\section{Supporting Data}

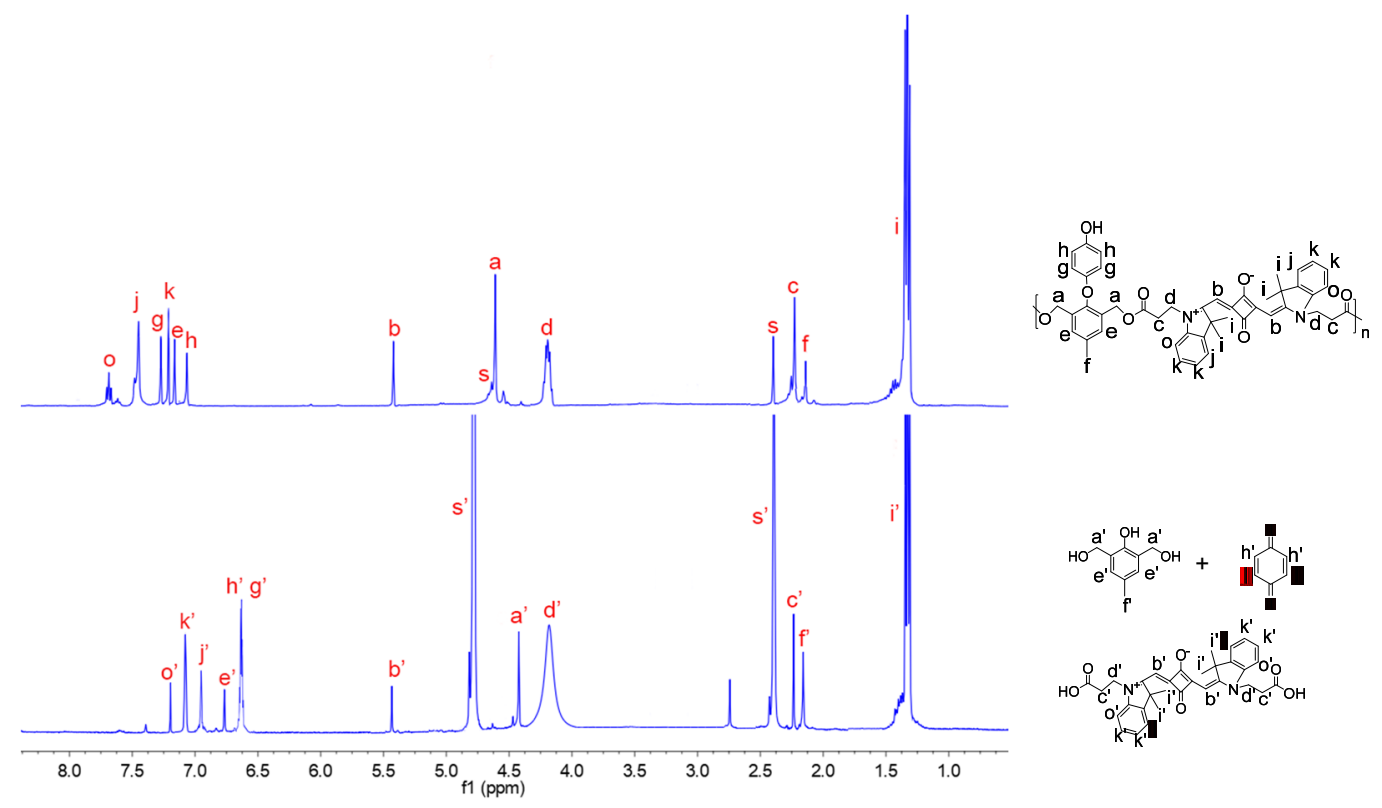

Figure S1. ${ }^{1} \mathrm{H}$ NMR spectra of polymer 1 in DMSO- $d_{6}$, deuterium PBS (above) and incubated with $\cdot \mathrm{OH}(40 \mu \mathrm{M}$, below) for $5 \mathrm{~h}$. "s" refers to solvent peaks.
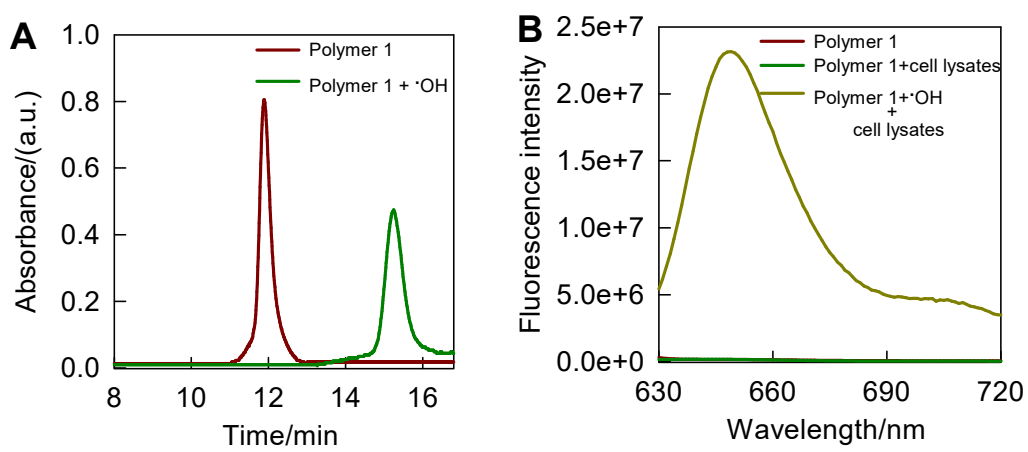

Figure S2. (A) GPC chromatograms of polymer 1 (red line) and incubated with $\cdot \mathrm{OH}$ (40 $\mu \mathrm{M}$, green line) for $5 \mathrm{~h}$. (B) Fluorescence emission spectra of polymer $1(120 \mu \mathrm{g} / \mathrm{mL})$ in phosphate buffer $(20 \mathrm{mM})$ under different conditions: polymer 1 only (red line), polymer $1+$ cell lysates $(8.0 \% \mathrm{w} / \mathrm{v}$, green line $)$, polymer $1+\cdot \mathrm{OH}(40 \mu \mathrm{M})+$ cell lysates $\left(8.0 \% \mathrm{w} / \mathrm{v}\right.$, yellow line). $\lambda_{\mathrm{ex}}=620 \mathrm{~nm}$. 

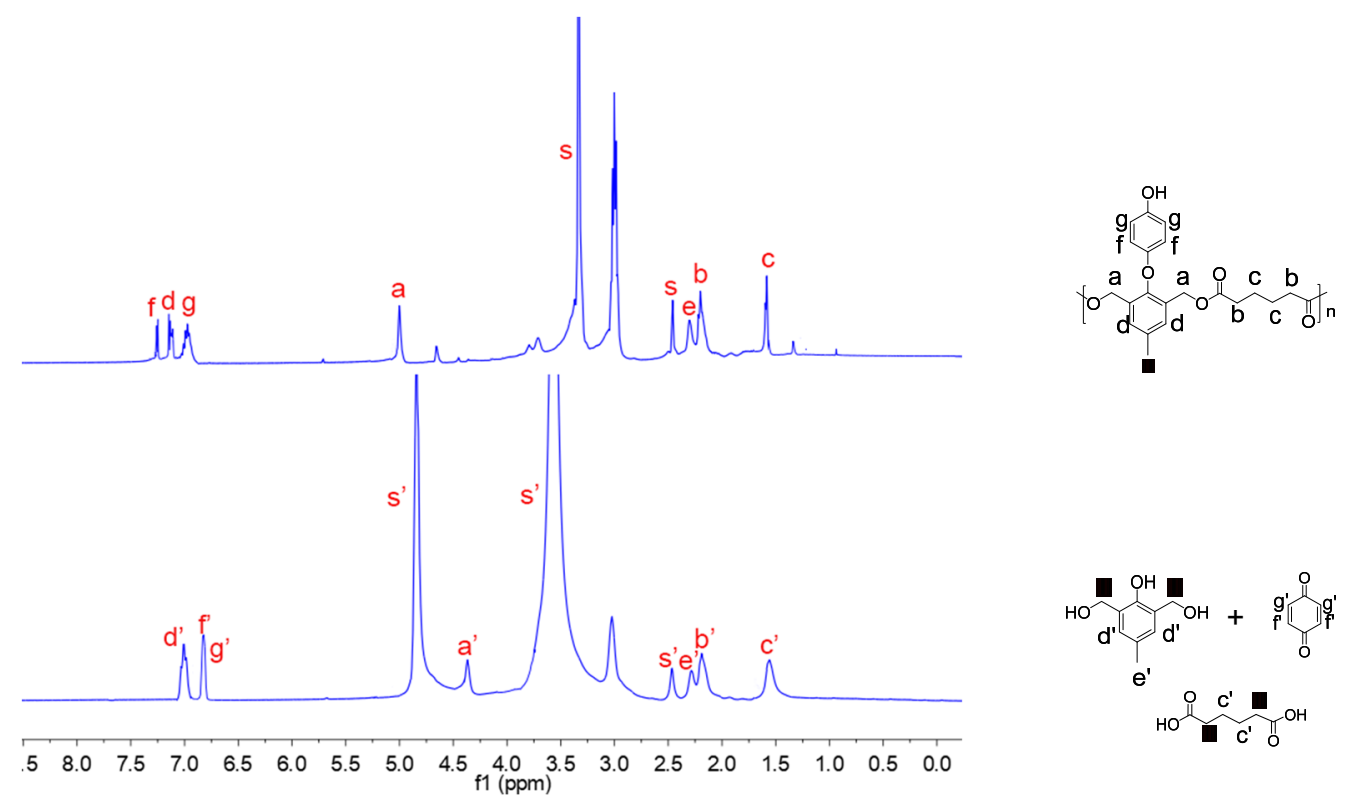

Figure S3. ${ }^{1} \mathrm{H}$ NMR spectra of polymer 2 in DMSO- $d_{6}$, deuterium PBS (above) and incubated with $\cdot \mathrm{OH}(40 \mu \mathrm{M}$, below) for $5 \mathrm{~h}$. "s" refers to solvent peaks.

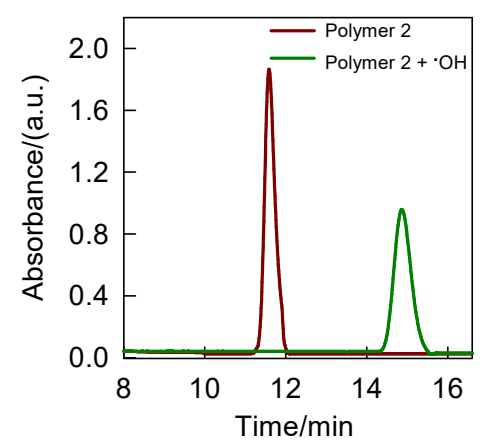

Figure S4. GPC chromatograms of polymer 2 (red line) and incubated with $\cdot \mathrm{OH}(40$ $\mu \mathrm{M}$, green line) for $5 \mathrm{~h}$. 
Scheme S1. Synthetic route of polymer 3.
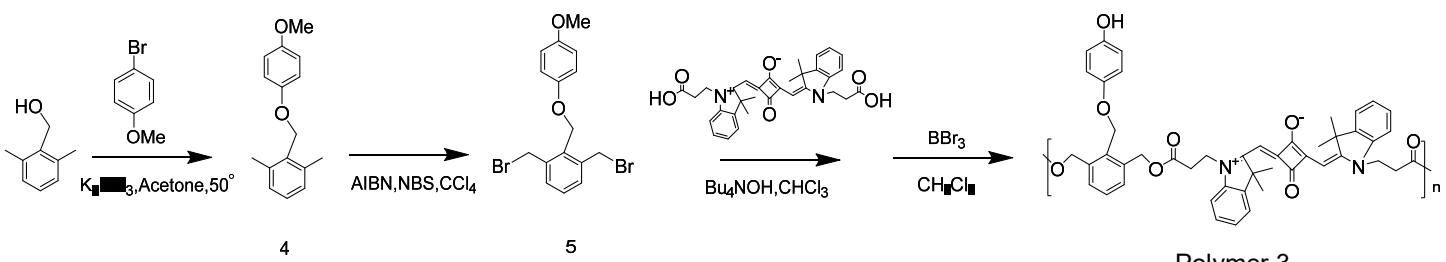

Polymer 3

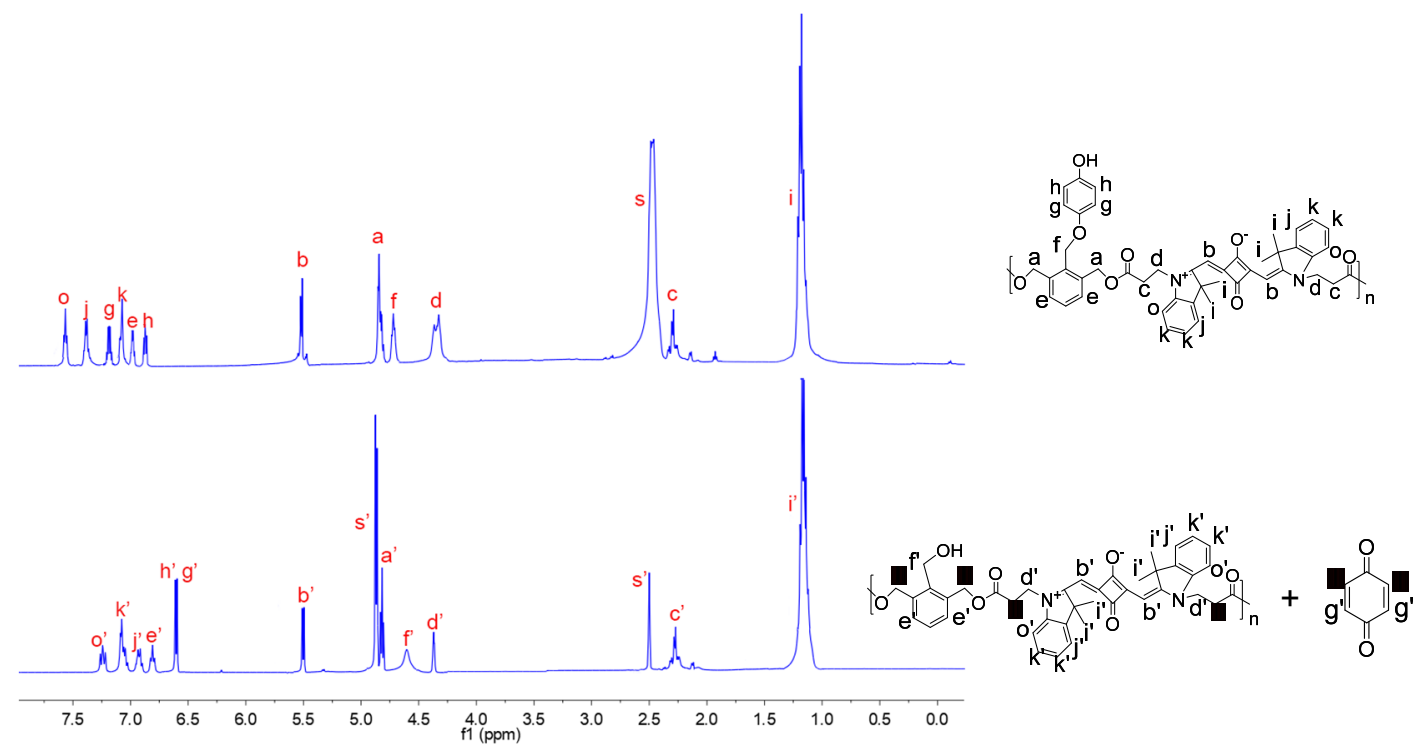

Figure S5. ${ }^{1} \mathrm{H}$ NMR spectra of polymer 3 in DMSO- $d_{6}$, deuterium PBS (above) and incubated with $\cdot \mathrm{OH}(40 \mu \mathrm{M}$, below) for $5 \mathrm{~h}$. "s" refers to solvent peaks. 

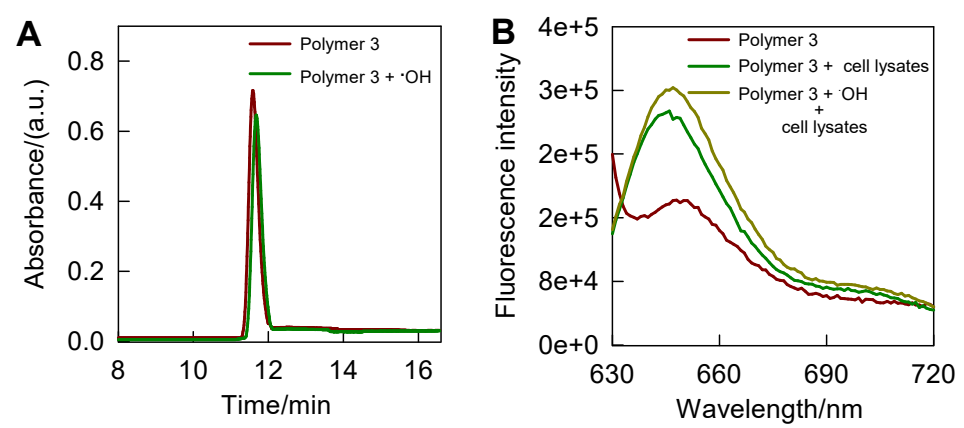

Figure S6. (A) GPC chromatograms of polymer 3 (red line) and incubated with $\cdot \mathrm{OH}$ (40 $\mu \mathrm{M}$, green line) for $5 \mathrm{~h}$. (B) Fluorescence emission spectra of polymer $3(120 \mu \mathrm{g} / \mathrm{mL})$ in phosphate buffer $(20 \mathrm{mM})$ under different conditions: polymer 3 only (red line), polymer $3+$ cell lysates $(8.0 \% \mathrm{w} / \mathrm{v}$, green line $)$, polymer $3+\cdot \mathrm{OH}(40 \mu \mathrm{M})+$ cell lysates $(8.0 \% \mathrm{w} / \mathrm{v}$, yellow line $) . \lambda_{\mathrm{ex}}=620 \mathrm{~nm}$

Scheme S2. Response mechanism of polymers 3 to $\cdot \mathrm{OH}$.

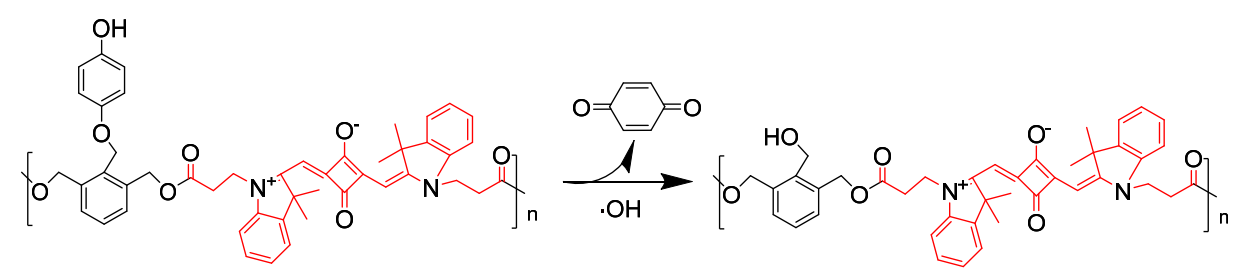



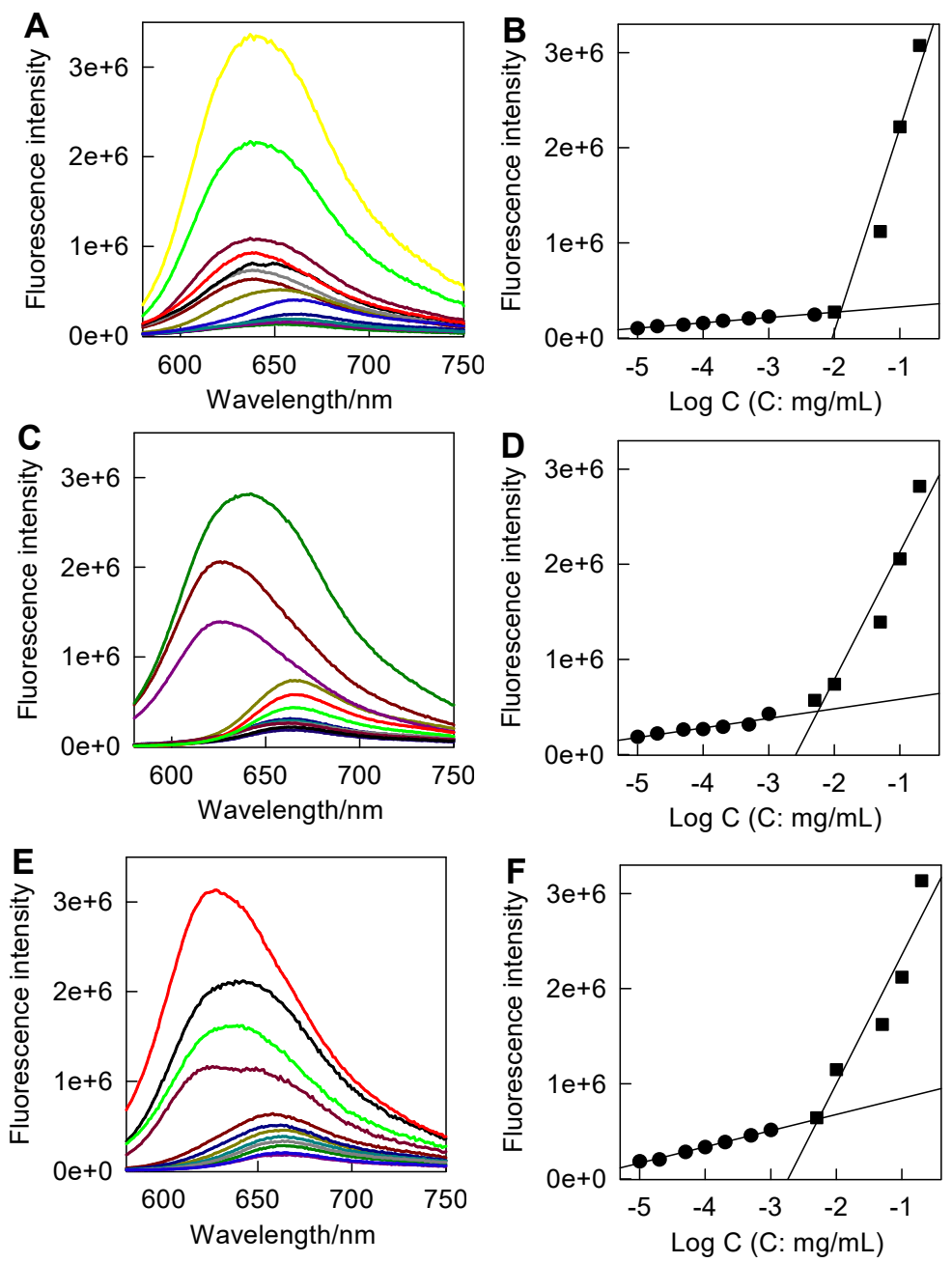

Figure S7. Fluorescence emission spectra of Nile Red in phosphate buffer $(20 \mathrm{mM})$ containing different concentrations of (A) polymer 1, (C) polymer 2 and (E) polymer 3 $(0.00001,0.000025,0.00005,0.0001,0.00025,0.0005,0.001,0.005,0.01,0.05,0.1$ and $0.2 \mathrm{mg} / \mathrm{mL}$ ). $\lambda_{\mathrm{ex}}=550 \mathrm{~nm}$. The relevant emission intensity at $630 \mathrm{~nm}$ versus the $\log$ of concentration of (B) polymer 1, (D) polymer 2 and (F) polymer 3. 

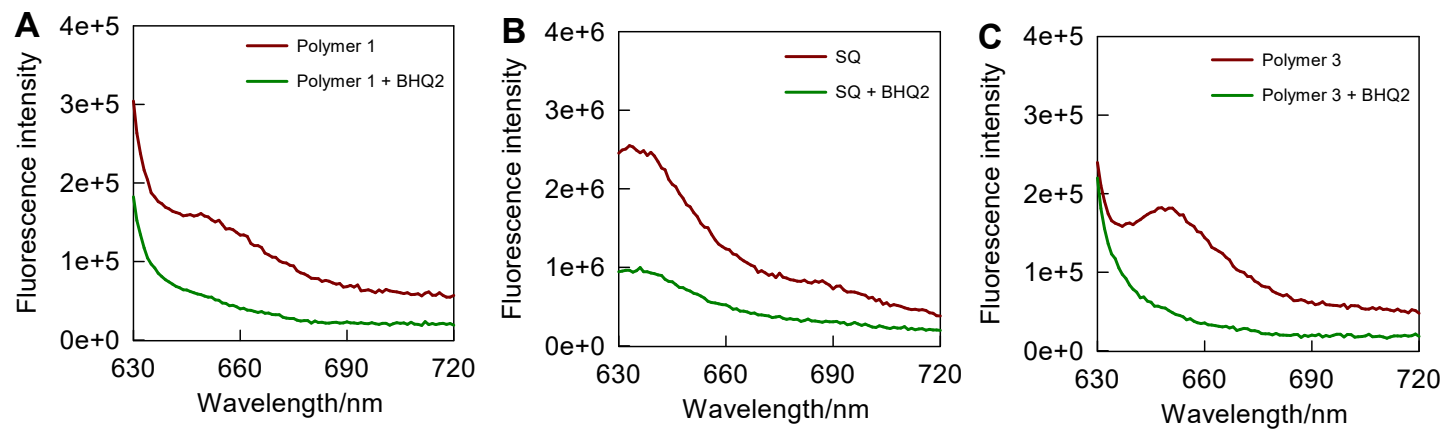

Figure S8. Fluorescence emission spectra of (A) polymer 1 and (C) polymer 3 (120 $\mu \mathrm{g} / \mathrm{mL}$ ) in the absence (red line) and presences (green line) of BHQ2 $(10 \mu \mathrm{M})$ in phosphate buffer $(20 \mathrm{mM})$. (B) Fluorescence emission spectra of SQ (5 $\mu \mathrm{M}$, red line) and after being treated with BHQ2 $(20 \mu \mathrm{M}$, green line) in phosphate buffer $(20 \mathrm{mM})$. $\lambda_{\mathrm{ex}}=620 \mathrm{~nm}$.
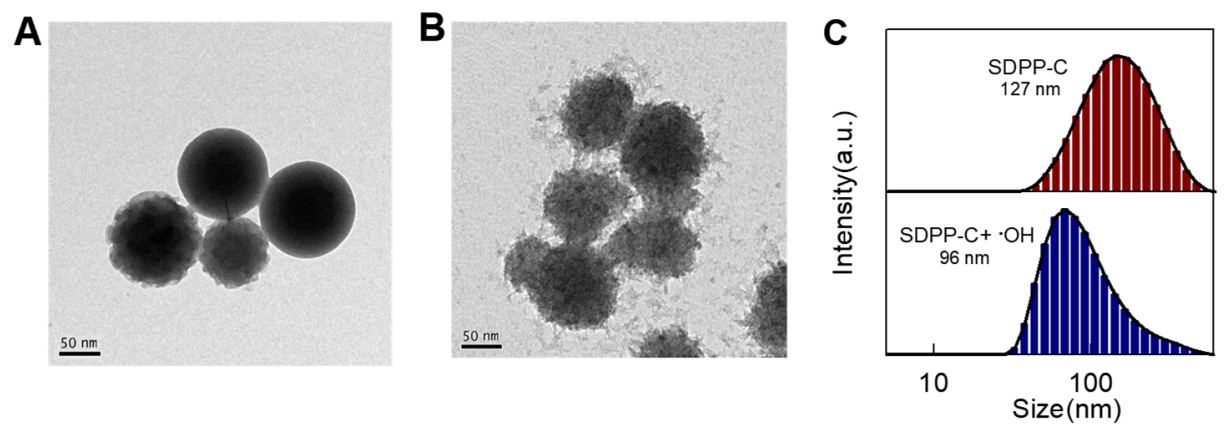

Figure S9. TEM images of SDPP-C in the absence (A) and presence (B) of $\cdot \mathrm{OH}(40$ $\mu \mathrm{M}$ ) in phosphate buffer, scale bars: $50 \mathrm{~nm}$. (C) DLS size distribution of SDPP before (above) and after (below) treated with $\cdot \mathrm{OH}(40 \mu \mathrm{M})$. 

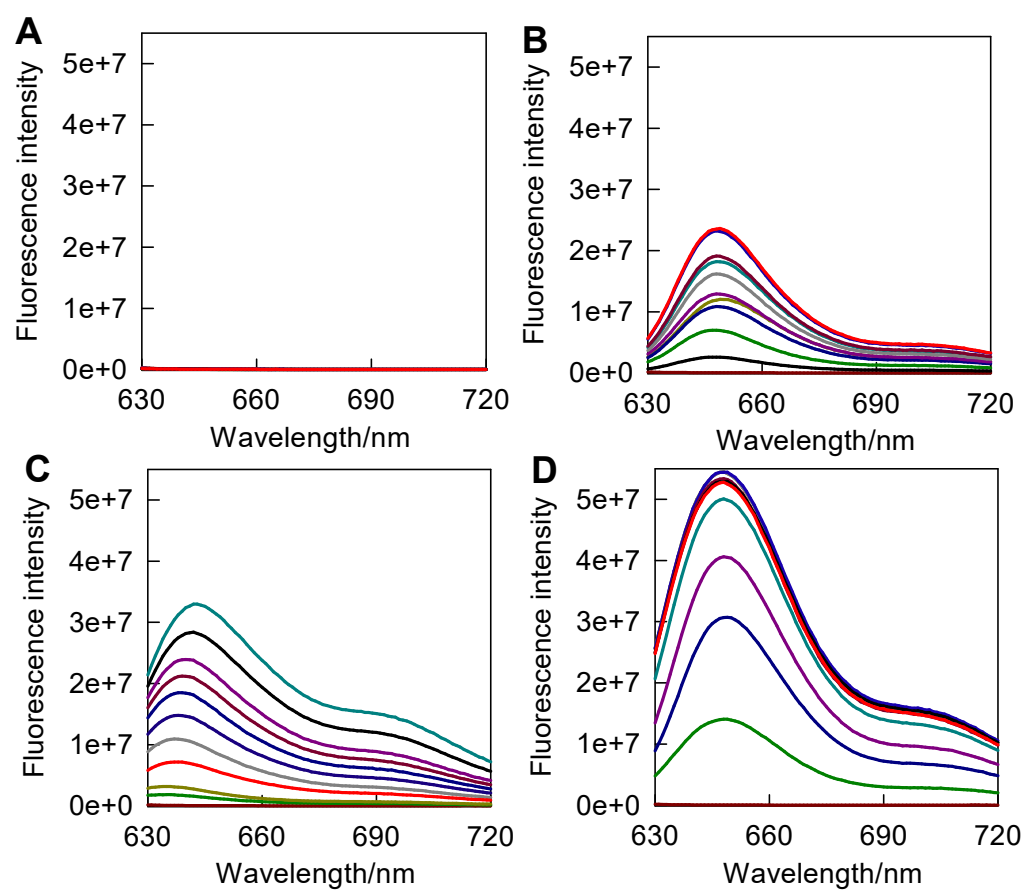

Figure S10. Fluorescence emission spectra of (A, B) SDPP and (C, D) dye-loaded nanoprobe in the absence $(\mathrm{A}, \mathrm{C})$ and presences $(\mathrm{B}, \mathrm{D})$ of $\cdot \mathrm{OH}(40 \mu \mathrm{M})$ in cell lysates from $\mathrm{H} 9 \mathrm{C} 2$ cells $(8 \%, \mathrm{w} / \mathrm{v})$ at different reaction time points. $\lambda_{\mathrm{ex}}=620 \mathrm{~nm}$. 

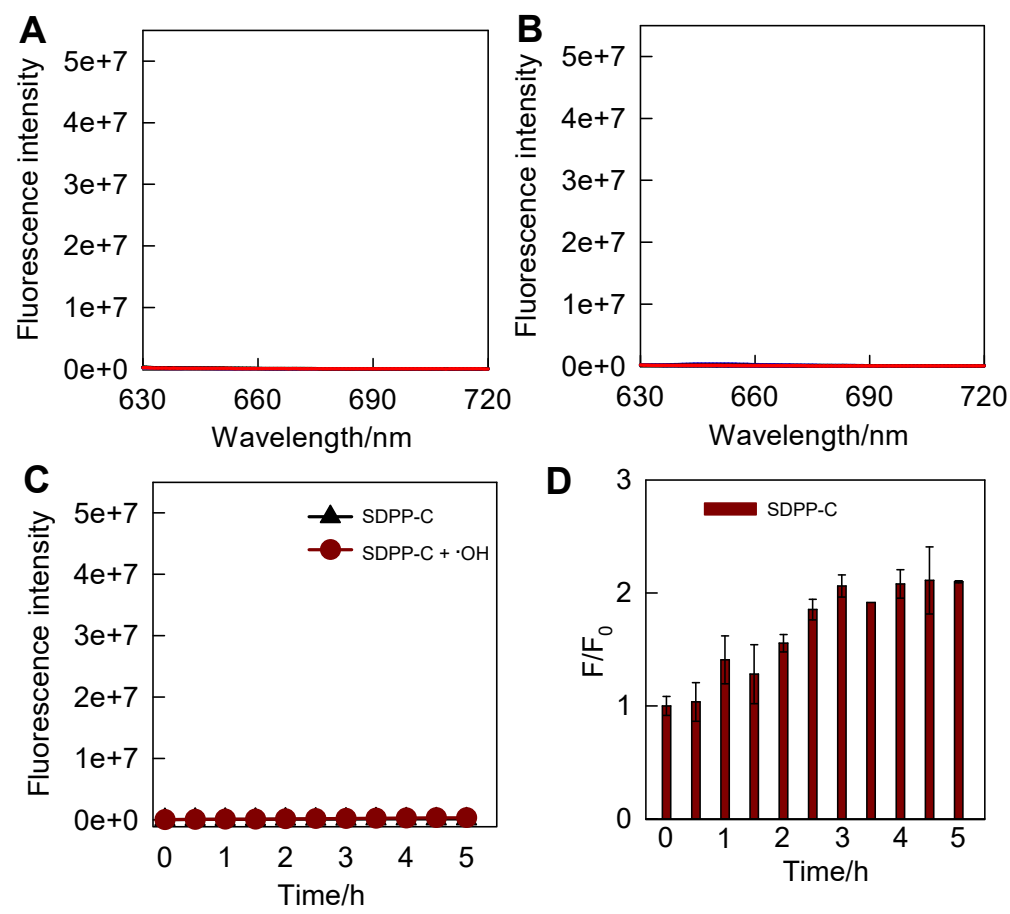

Figure S11. Fluorescence emission spectra of SDPP-C before (A) and after (B) being treated with $\cdot \mathrm{OH}(40 \mu \mathrm{M})$ in cell lysates from $\mathrm{H} 9 \mathrm{C} 2$ cells $(8 \%$, w/v) at different reaction time points. $\lambda_{\mathrm{ex}}=620 \mathrm{~nm}$. (C) The real-time monitoring of fluorescence emission at 647 nm of SDPP-C $(120 \mu \mathrm{g} / \mathrm{mL})$ in the absence (black) and presence (red) of $\cdot \mathrm{OH}(40 \mu \mathrm{M})$ in cell lysates from $\mathrm{H} 9 \mathrm{C} 2$ cells $\left(8 \%\right.$, w/v). (D) The corresponding $F / F_{0}$ values of SDPP$C$ at different point of time. Error bars represent \pm SD $(n=3)$.
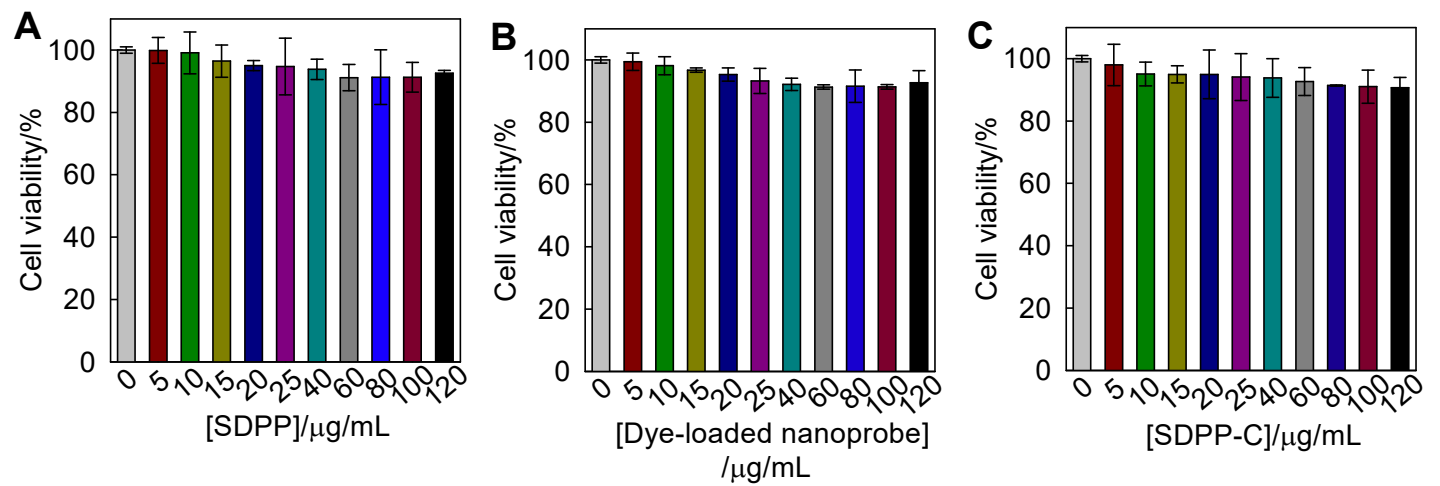

Figure S12. Cell viability of $\mathrm{H} 9 \mathrm{C} 2$ cells after being incubated with different concentration of (A) SDPP1, (B) dye-loaded nanoprobe and (C) SDPP-C for $24 \mathrm{~h}$. The results are the mean \pm standard deviation of three measurements. 

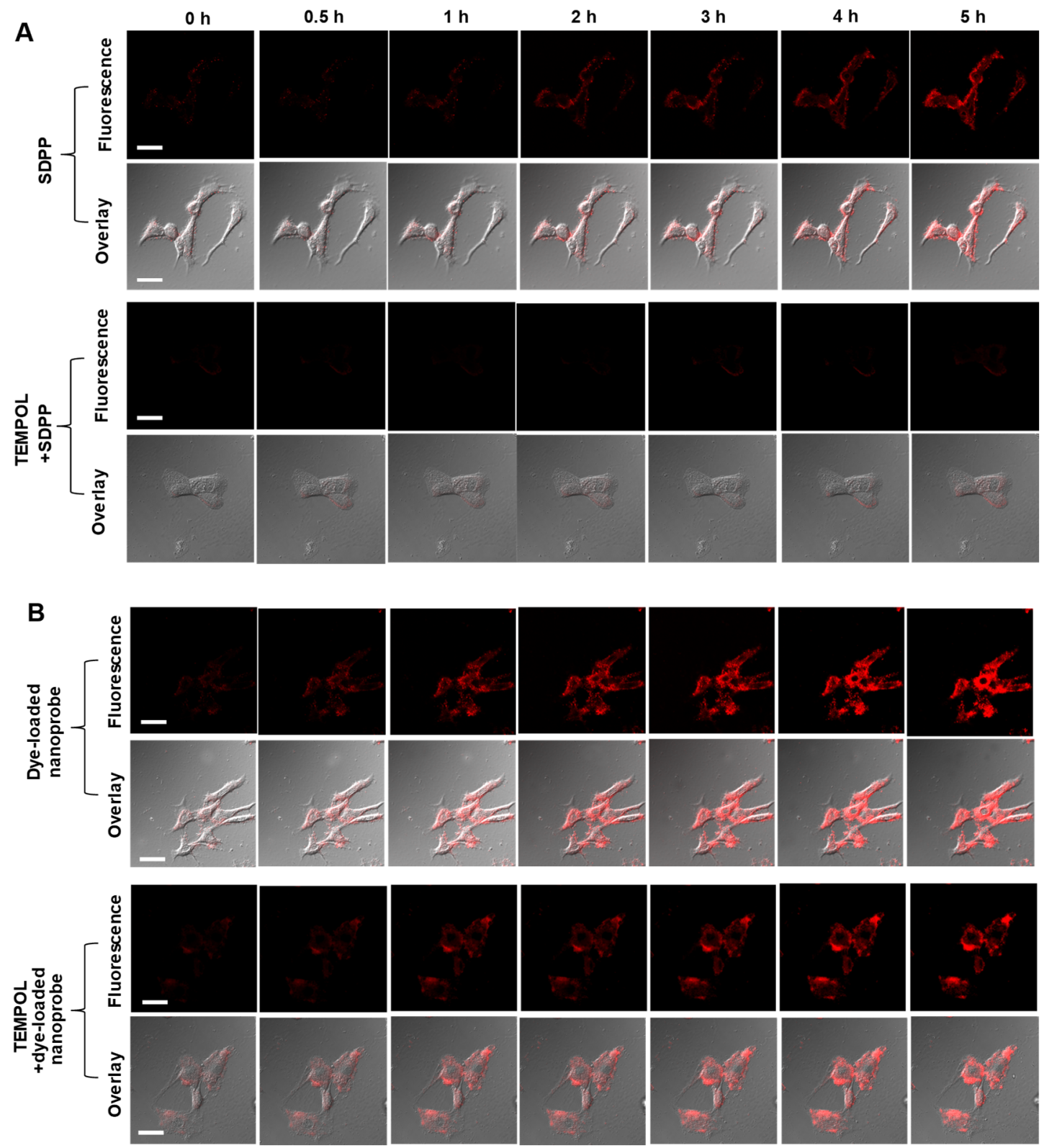

Figure S13. Confocal laser fluorescence images of (A) SDPP (120 $\mu \mathrm{g} / \mathrm{mL})$ and (B) dye-loaded nanoprobe $(120 \mu \mathrm{g} / \mathrm{mL})$ incubated with H9C2 cells for $0,0.5,1,2,3,4$ and $5 \mathrm{~h}$ at different conditions: SDPP only $(120 \mu \mathrm{g} / \mathrm{mL}$, first line); pretreated with TEMPOL (1.0 $\mathrm{mM})$, further incubated with SDPP $(120 \mu \mathrm{g} / \mathrm{mL}$, second line); dye-loaded nanoprobe only $(120 \mu \mathrm{g} / \mathrm{mL}$, third line); pretreated with TEMPOL (1.0 mM), further incubated with dye-loaded nanoprobe only $(120 \mu \mathrm{g} / \mathrm{mL}$, fourth line), scale bars: $20 \mu \mathrm{m}$. $\lambda_{\mathrm{ex}}=640 \mathrm{~nm}, \lambda_{\mathrm{em}}=650-700 \mathrm{~nm}$. 

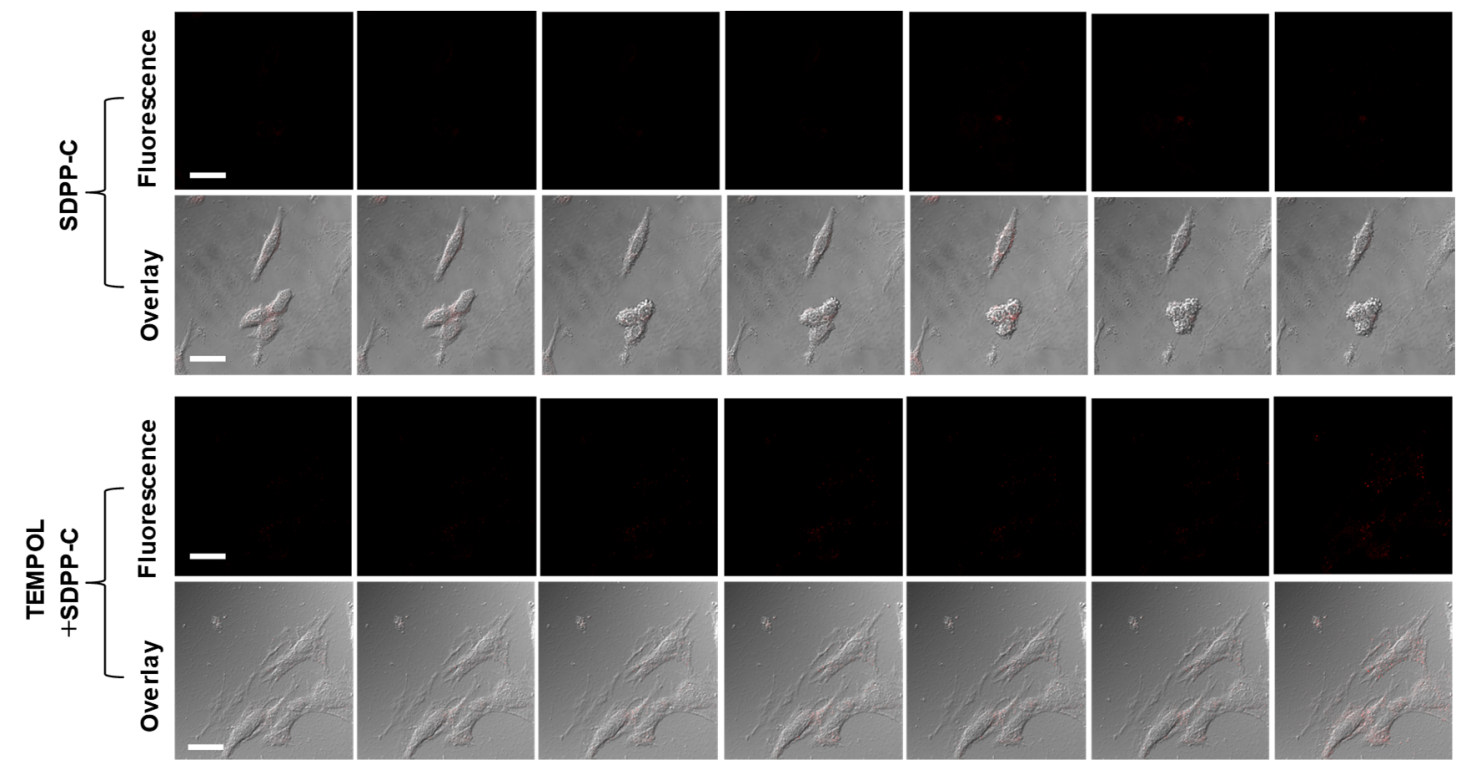

Figure S14. Confocal laser fluorescence images of SDPP-C $(120 \mu \mathrm{g} / \mathrm{mL})$ incubated with H9C2 cells for $0,0.5,1,2,3,4$ and $5 \mathrm{~h}$ at different conditions: SDPP-C only (120 $\mu \mathrm{g} / \mathrm{mL}$, first line); pretreated with TEMPOL (1.0 mM), further incubated with SDPP-C $\left(120 \mu \mathrm{g} / \mathrm{mL}\right.$, second line), scale bars: $20 \mu \mathrm{m} . \lambda_{\mathrm{ex}}=640 \mathrm{~nm}, \lambda_{\mathrm{em}}=650-700 \mathrm{~nm}$. 

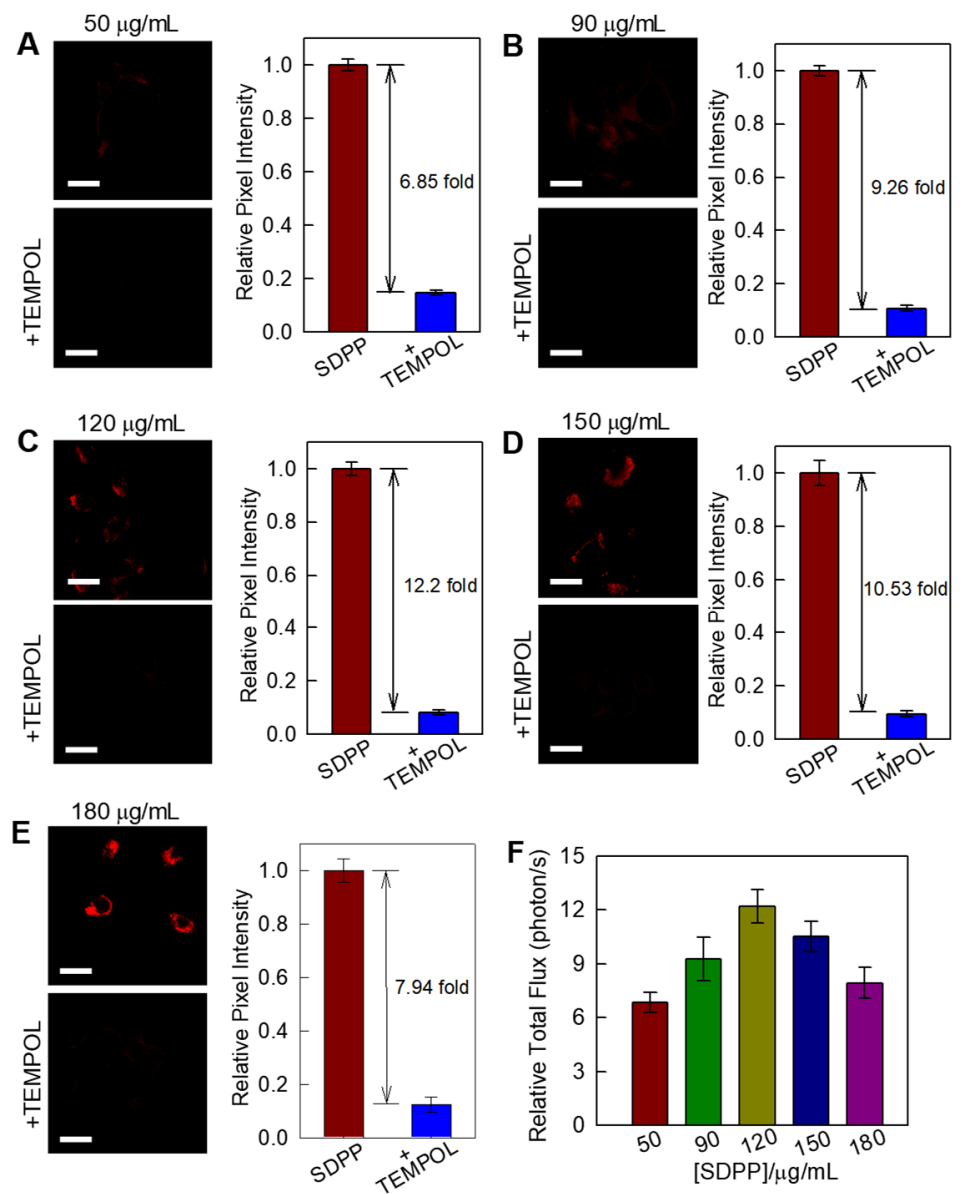

Figure S15. (A)-(E) Confocal fluorescence images of H9C2 cells incubated with different concentration of SDPP for $5 \mathrm{~h}$ in the absence (above) and presence (below) of TEMPOL $(1.0 \mathrm{mM})$, scale bars: $20 \mu \mathrm{m} . \lambda_{\mathrm{ex}}=640 \mathrm{~nm}, \lambda_{\mathrm{em}}=650-700 \mathrm{~nm}$. (F) The relative pixel intensity of corresponding fluorescence images of living cells treated with different concentration of SDPP, the pixel intensity from image of cells treated with SDPP is defined as 1.0. Error bars indicate s.d. $(n=3)$. 

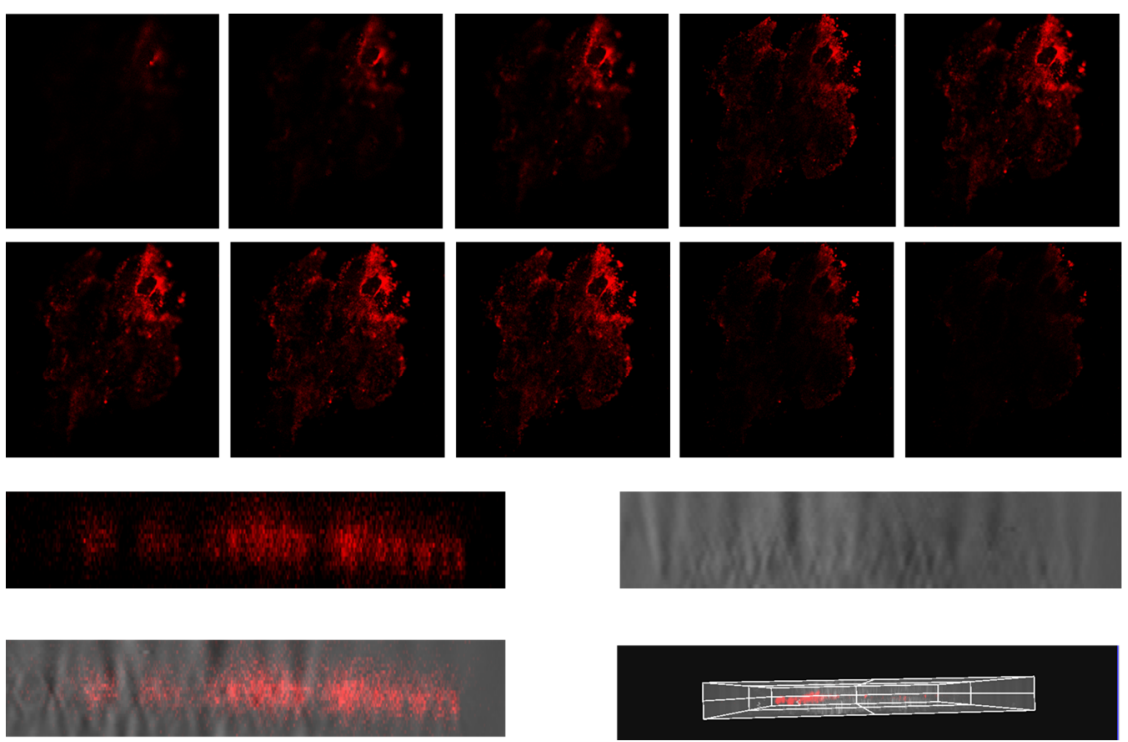

Figure S16. 3D fluorescence images of H9C2 cells incubated with SDPP $(120 \mu \mathrm{g} / \mathrm{mL})$ for $5 \mathrm{~h}$. 

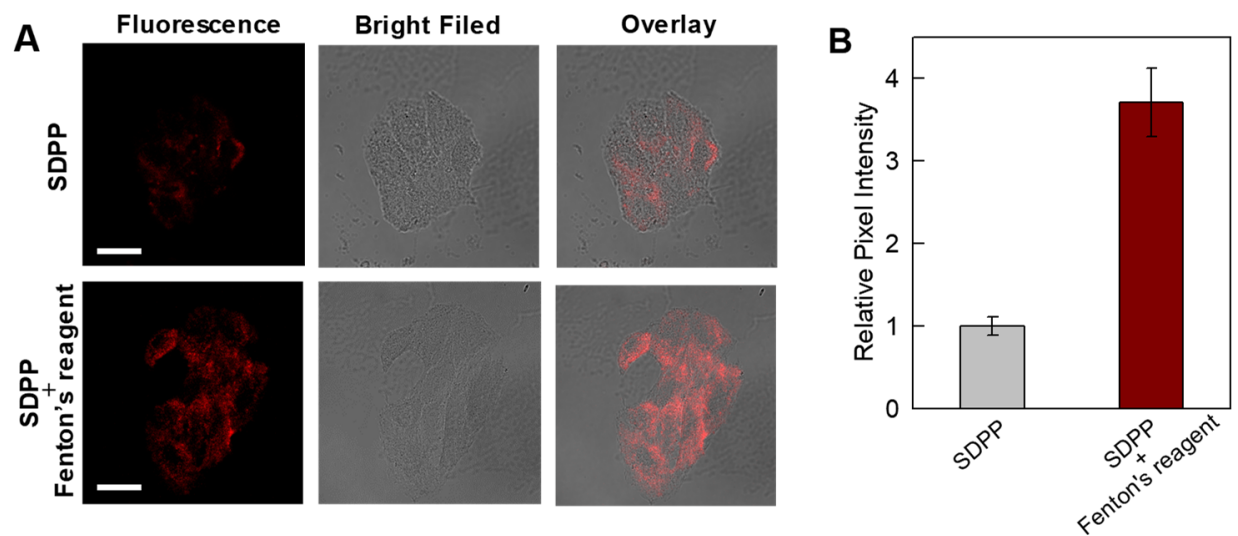

Figure S17. (A) Confocal fluorescence images of H9C2 cells incubated with SDPP under different conditions: SDPP only $(120 \mu \mathrm{g} / \mathrm{mL}$, above); treatment of Fenton's reagent $(10 \mu \mathrm{M})$. The incubation time is $5 \mathrm{~h}$. Scale bars: $20 \mu \mathrm{m} . \lambda_{\mathrm{ex}}=640 \mathrm{~nm}, \lambda_{\mathrm{em}}=$ 650-700 nm. (B) The corresponding relative pixel intensity of images in (A), and the pixel intensity from image of cells incubated with SDPP is defined as 1.0. Error bars represent $\pm \operatorname{SD}(\mathrm{n}=3)$.

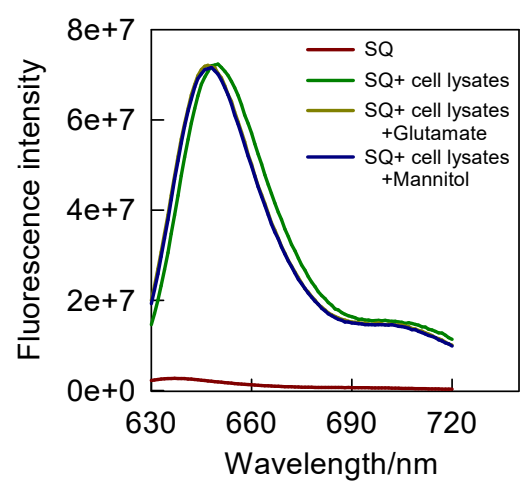

Figure S18. Fluorescence emission spectra of SQ $(5.0 \mu \mathrm{M})$ in phosphate buffer $(20$ $\mathrm{mM})$ under different conditions: SQ only (red line); SQ + cell lysates $(8.0 \% \mathrm{w} / \mathrm{v}$, green line); SQ + cell lysates $(8.0 \% \mathrm{w} / \mathrm{v})+$ glutamate $(10.0 \mathrm{mM}$, yellow line $) ; \mathrm{SQ}+$ cell lysates $(8.0 \% \mathrm{w} / \mathrm{v})+$ mannitol $(10.0 \mathrm{mM}$, blue line $)$. 


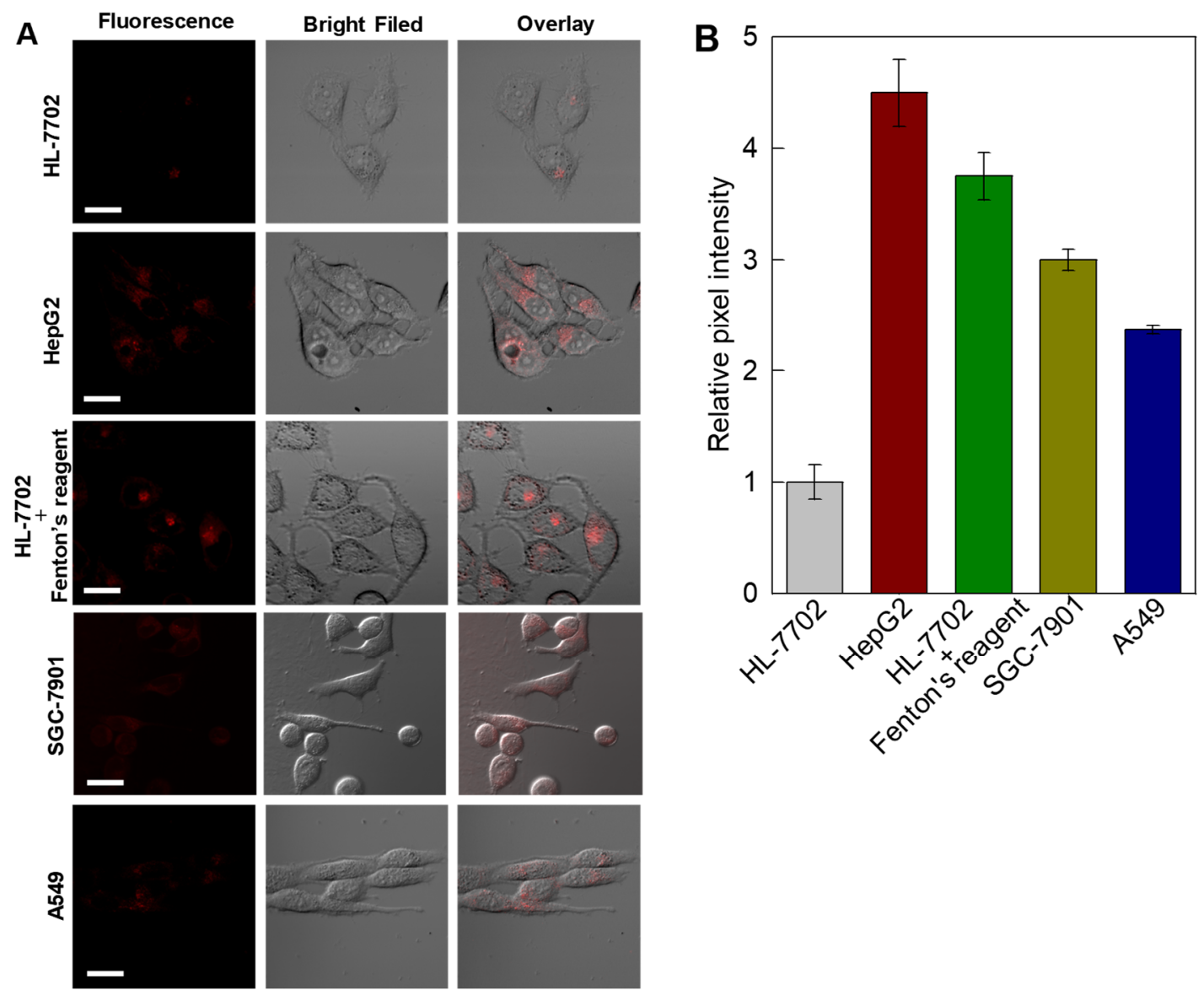

Figure S19. (A) Confocal microscopy images of various cell lines incubated with SDPP $(120 \mu \mathrm{g} / \mathrm{mL})$ for $5 \mathrm{~h}$, scale bars: $20 \mu \mathrm{m}$. $\lambda_{\mathrm{ex}}=640 \mathrm{~nm}, \lambda_{\mathrm{em}}=650-700 \mathrm{~nm}$. (B) The relative pixel intensity of the fluorescence images shown in A, where the pixel intensity from image of HL-7702 is defined as 1.0, and error bars indicate s.d. $(n=3)$. 

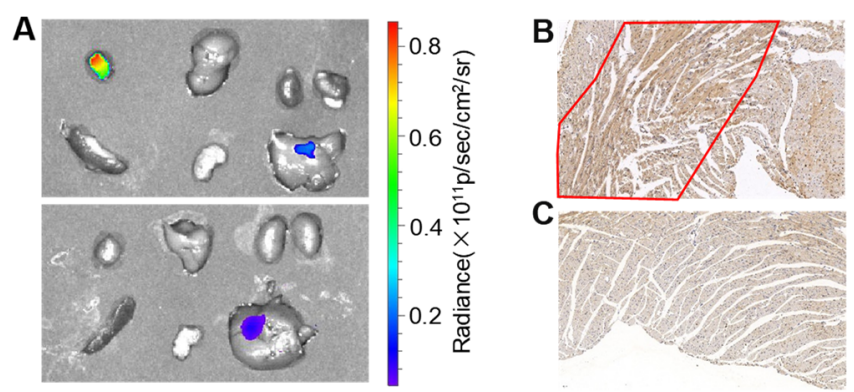

Figure S20. (A) Fluorescence images of various organ stripped from myocarditic (above) and normal (below) mice intraperitoneally injected with SDPP $(120 \mu \mathrm{g} / \mathrm{mL})$. $\lambda_{\mathrm{ex}}=600 \mathrm{~nm} ; \lambda_{\mathrm{em}}=670-740 \mathrm{~nm}$. Immunohistochemistry staining analysis of CD11b in (B) inflamed and (C) normal heart. The images were $20 \times$ the original magnification. The marked sites represent the cellular infiltration with neutrophile granulocyte.

\section{References}

(1) Lux, C. G.; Joshi-Barr, S.; Nguyen, T.; Mahmoud, E.; Schopf, E.; Fomina, N.; Almutairi, A. Biocompatible Polymeric Nanoparticles Degrade and Release Cargo in Response to Biologically Relevant Levels of Hydrogen Peroxide. J. Am. Chem. Soc. 2012, 134, 15758-15764.

(2) Bai, X.; Huang, Y.; Lu, M.; Yang, D. HKOH-1: A Highly Sensitive and Selective Fluorescent Probe for Detecting Endogenous Hydroxyl Radicals in Living Cells. Angew. Chem., Int. Ed. 2017, 56, 12873-12877.

(3) Yan, Q.; Sang, W. $\mathrm{H}_{2} \mathrm{~S}$ Gasotransmitter-Responsive Polymer Vesicles. Chem. Sci., 2016, 7, 2100-2105.

(4) Ciapetti, G.; Cenni, E.; Pratelli, L.; Pizzoferrato, A. In Vitro Evaluation of Cell/biomaterial Interaction by MTT Assay. Biomaterials, 1993, 14, 359-364. 